\title{
HUBUNGAN SELF EFFICACY DENGAN MOTIVASI SISWA DALAM BERWIRAUSAHA BERBASIS BIOLOGI
}

\author{
The Correlation between Self Efficacy with Students Motivation in Bioentrepreneurship
}

\author{
Ernawati, Erna Heryanti, Nurul Try Mentari \\ Pendidikan Biologi, Fakultas MIPA, Universitas Negeri Jakarta \\ Email: ernaoke2011@gmail.com
}

\begin{abstract}
Entrepreneurship is required to create a human resources quality in managing natural resources wisely and have the independence. The entrepreneurial spirit supported by self efficacy and motivation used to encourage students in entrepreneurship. Entrepreneurship can be honed and formed through education. This study aims to determine the correlation between self efficacy with students motivation in bioentrepreneurship. The study was conducted in SMA Negeri 98 Jakarta on April until May 2016. The reseach method used is survey, the correlation technique with a sample size of 125 students were taken by simple random sampling. Data collection techniques used questionnaire self efficacy of student in bioentrepreneurship and questionnaire motivation of student in bioentrepreneurship. The data of self efficacy and motivation of students in bioentrepreneurship is normal distribution and homogeneous. The results from this study show that there is a significant positive relation between self efficacy and students motivation in bioentrepreneurship with a correlation coefficient amounted to 0,725 . Self efficacy contribute $52,5 \%$ for students motivation in bioentrepreneurship.
\end{abstract}

\section{Keyword: self efficacy, motivation, bioentrepreneurship.}

\section{PENDAHULUAN}

Kewirausahaan merupakan kemampuan yang dibutuhkan saat ini, untuk menjadikan pribadi yang mandiri. Jiwa kewirausahaan juga diperlukan untuk menciptakan sumber daya manusia (SDM) yang berkualitas dalam mengelola sumber daya alam (SDA) secara bijak dan mandiri dan tetap memperhatikan aspek lingkungan. Menurut (Bolton dan Thomson, 2004 dalam Wahyudi, 2012) terdapat tiga faktor yang dapat mempengaruhi seseorang untuk menjadi entrepreneur (wirausaha), yaitu latar belakang orang tua, usia, pengalaman kerja, dan pendidikan. Kewirausahaan dapat diasah dan terbentuk melalui pendidikan.

Pendidikan di Indonesia sudah mengacu pada kurikulum 2013. Dalam penerapan kurikulum ini, ada beberapa karakter yang ditanamkan di dalam diri siswa seperti kemandirian, kejujuran, keterampilan, bertanggung jawab, peduli lingkungan, kreatif, dan cinta tanah air. Pada kurikulum ini, terdapat mata pelajaran Prakarya dan Kewirausahaan di tingkat Sekolah Menengah Atas (SMA) dan sederajat. Pada mata pelajaran ini terdapat beberapa ruang lingkup yang dipelajari dan berkaitan erat dengan aspek biologis yaitu budidaya, dan pengolahan.

Seseorang yang memiliki jiwa kewirausahaan memiliki karakteristik yaitu passion (minat), independent (mandiri), market sensitivity (peka terhadap pasar), 
creative dan innovative (kreatif dan inofativ), calculated risk taker (berani mengambil resiko), persistent (gigih), high ethical standard (memiliki etika), memiliki motivasi yang tinggi, dan self efficacy (Wahyudi, 2012; Meredith et al, 1996; Drnovsek, 2010)

Self efficacy (efikasi diri) adalah suatu keyakinan diri untuk melakukan sesuatu yang spesifik hingga tuntas. Self efficacy dapat membentuk proses motivasi (Bandura, 1994). Motivasi merupakan suatu dorongan yang muncul pada diri seseorang untuk melakukan sesuatu. Menurut (Pintrinch dan DeGroot 1990 dalam Lai, 2011) seseorang yang memiliki self efficacy tinggi, lebih termotivasi dan sukses dalam menyelesaikan suatu tugas. Hal ini perlu ditanamkan di dalam diri siswa agar memiliki keyakinan diri dan motivasi dalam memulai suatu usaha dan membentuk kemandirian.

Untuk membuktikan hubungan self efficacy dengan motivasi siswa dalam berwirausaha berbasis biologi maka dilakukan kajian melalui penelitian.

\section{METODE}

Penelitian ini adalah untuk mengukur self efficacy siswa dalam berwirausaha berbasis biologi dan motivasi siswa dalam berwirausaha berbasis biologi. Penelitian ini dilakukan di SMA Negeri 98 Jakarta, pada semester genap. Tahun Ajaran 2015/ 2016. Metode penelitian ini menggunakan metode survai dengan studi korelasional. Sampel yang digunakan adalah siswa SMA kelas XI MIA yang berjumlah 125 siswa.

\section{PROSEDUR ANALISIS DATA}

Teknik analisis data yang digunakan adalah sebagai berikut:

1. Uji Prasyarat Analisis

a. Uji Normalitas

Uji normalitas dilakukan untuk mengetahui kenormalan data. Uji normalitas dihitung dengan menggunakan Uji Kolmogorov-Smirnov untuk $\alpha=0,05$ menggunakan SPSS versi 21.

b. Uji Homogenitas

Uji yang digunakan dalam uji homogenitas adalah uji Levene menggunakan SPSS versi 21. Uji ini dilakukan untuk mengetahui apakah sampel yang diambil tingkat homogenitasnya sama.

\section{Uji Hipotesis}

Uji hipotesis penelitian yang digunakan dalam penelitian ini adalah uji regresi dan korelasi. Langkah pertama yang dilakukan adalah melihat hubungan antara dua variabel dengan menggunakan analisis regresi linier sederhana. Analisis kemudian dilanjutkan dengan uji korelasi yang bertujuan mengetahui derajat hubungan antar variabel. Uji korelasi yang digunakan adalah uji korelasi Pearson Product Moment menggunakan

SPSS versi 21dengan menghitung $r_{x y}$ pada $\alpha=0,05$. Harga $r_{x y}$ yang diperoleh kemudian diinterpretasikan tingkat hubungannya. 


\section{HASIL DAN PEMBAHASAN}

\section{Hasil}

1. Nilai self efficacy siswa dalam berwirausaha berbasis biologi yang tertinggi dari 125 siswa adalah 93 dan nilai terendah adalah 52 . Nilai rata-rata motivasi berwirausaha siswa adalah 73 dengan simpangan baku 7,3. Rentang nilai 73,678 sebanyak 38 siswa $(30,4 \%)$ dan paling sedikit terdapat pada rentang nilai 5256,4 dan 89,8-94,2 sebanyaksiswa (1,6\%). dapat dilihat pada gambar.1

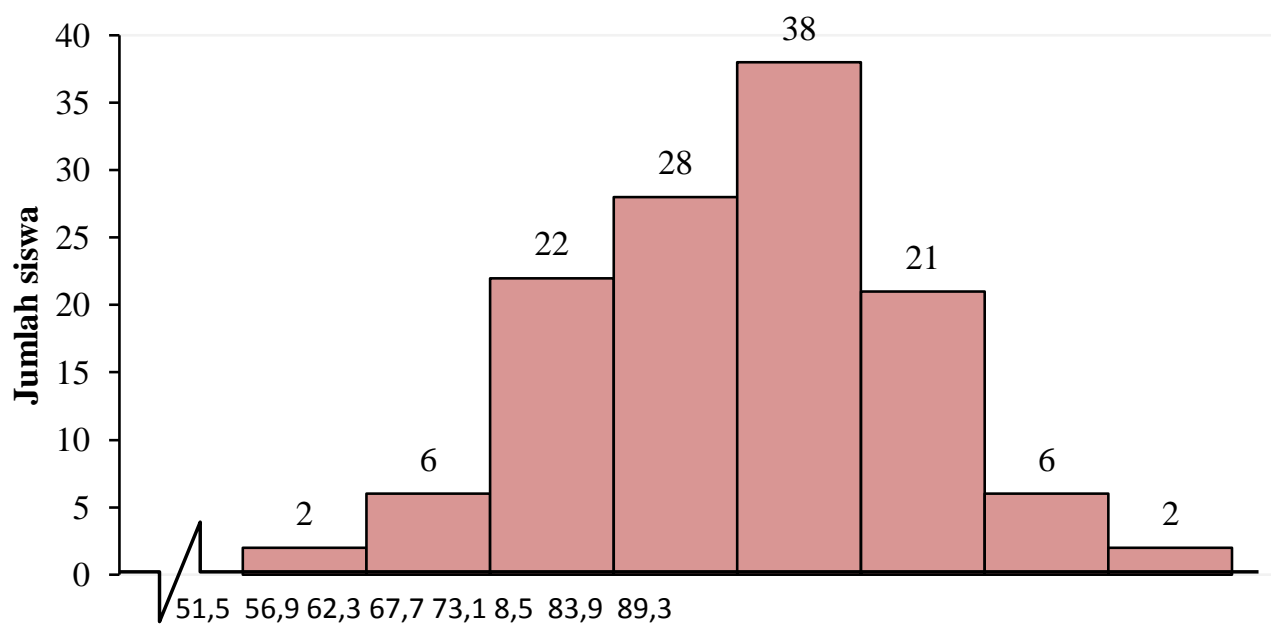

Rentang Nilai self efficacy dalam Berwirausaha Berbasis Biologi

Gambar.1 Rentang Nilai Self Efficacy Siswa dalam Berwirausaha

2. Berdasarkan nilai yang diperoleh dari 125 siswa, sebanyak 18 siswa termasuk kategori sangat tinggi. Sebanyak 100 siswa termasuk kategori tinggi, sedangkan 7 orang siswa termasuk pada kategori cukup. Persentase nilai self efficacy siswa dalam berwirausaha berbasis biologi berdasarkan pengkategorian ditampilkan pada gambar.2:

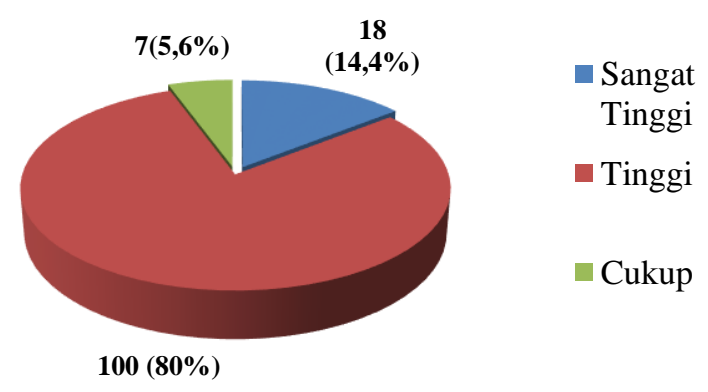

Gambar 2. Persentase Kategori Nilai Self Efficacy Siswa dalam Berwirausaha Berbasis biologi 
3. Berdasarkan persentase rata-rata, dimensi yang tertinggi adalah menetukan tujuan inti sebesar $17,4 \%$, dan terendah adalah menghadapi tantangan tak terduga sebesar $16,1 \%$. Persentase rata-rata keenam dimensi self efficacy dalam berwirausaha berbasis biologi disajikan pada gambar 3:

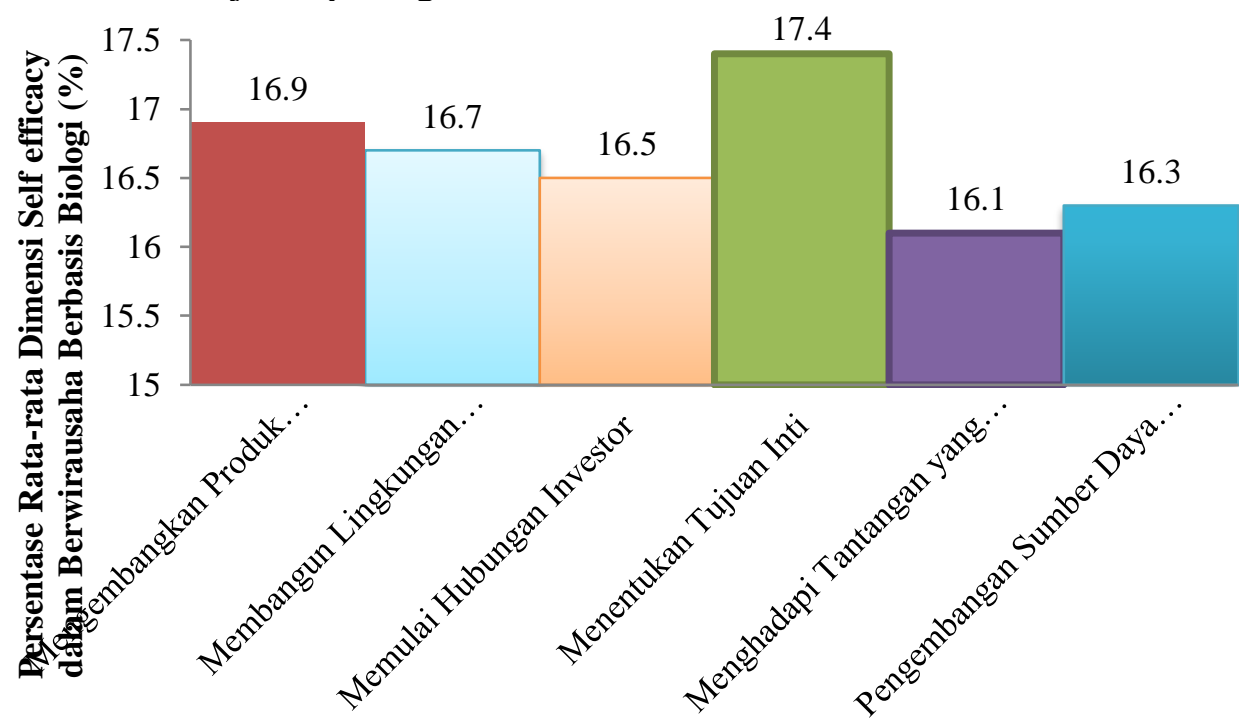

Dimensi Self Efficacy dalam Berwirausaha Berbasis Biologi

Gambar.3 Persentase Rata-Rata setiap Dimensi Self Efficacy dalam Berwirausaha Berbasis Biologi

4. Nilai motivasi siswa dalam berwirausaha berbasis biologi yang tertinggi dari 125 siswa adalah 96 dan nilai terendah adalah 58. Nilai rata-rata motivasi berwirausaha siswa adalah 80. Frekuensi nilai motivasi berwirausaha siswa yang paling banyak terdapat pada rentang nilai 73-77, sebanyak 35 siswa (28\%) dan paling sedikit terdapat pada rentang nilai 58-62 sebanyak 2 siswa (1,6\%). Distribusi frekuensi nilai motivasi berwirausaha siswa dapat dilihat pada gambar.4: 


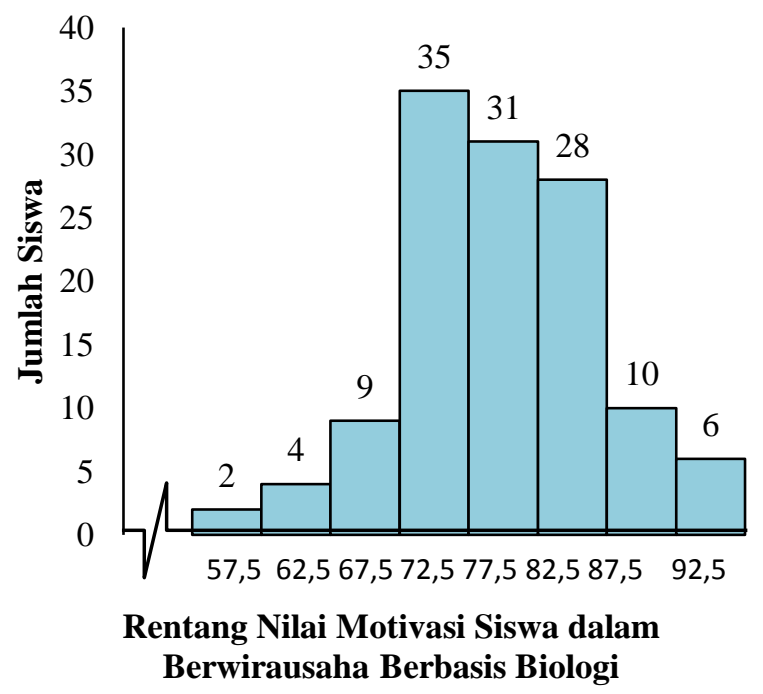

Gambar 4. Rentang Nilai Motivasi siswa dalam Berwirausaha Berbasis Biologi

5. Berdasarkan nilai yang diperoleh dari 125 siswa, sebanyak 59 siswa termasuk kategori sangat tinggi. Sebanyak 65 siswa termasuk kategori tinggi, sedangkan 1 orang siswa termasuk pada kategori cukup. Persentase nilai motivasi siswa dalam berwirausaha berbasis biologi berdasarkan pengkategorian ditampilkan pada gambar.5:

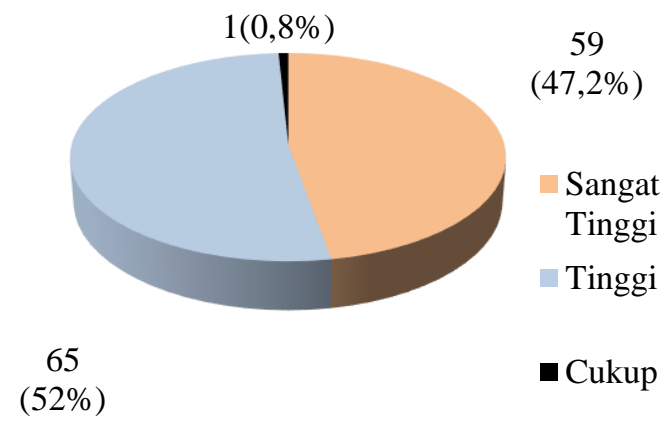

Gambar.5 Persentase Nilai Motivasi Siswa dalam Berwirausaha Berbasis Biologi

6. Berdasarkan persentase rata-rata, dimensi yang tertinggi adalah kebutuhan yang tersedia $28,2 \%$, sedangkan yang terendah adalah personal (diri) dan lingkungan sosial sebesar 17,6\%.. Persentase rata-rata keenam dimensi motivasi dalam berwirausaha berbasis biologi disajikan pada gambar 6: 


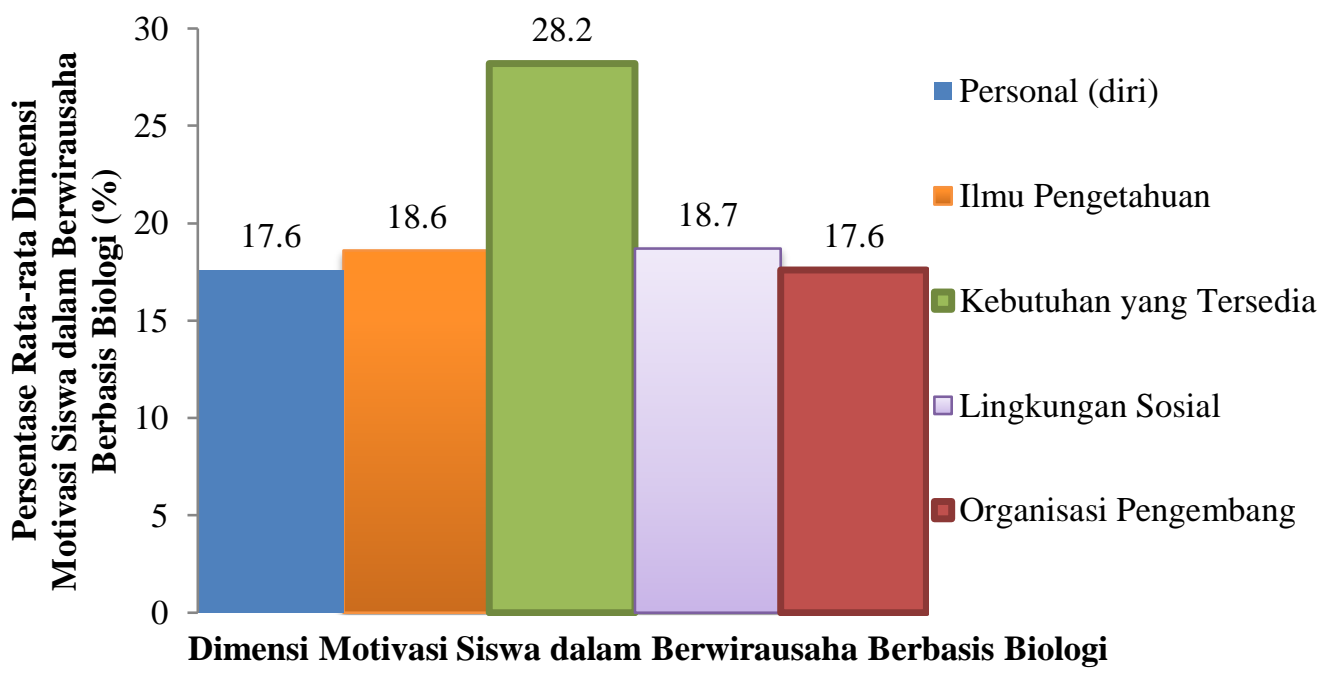

Gambar.6 Persentase Rata-Rata setiap Dimensi Motivasi dalam Berwirausaha Berbasis Biologi

\section{Pembahasan}

Penelitian ini menunjukkan adanya hubungan positif antara self efficacy dalam berwirausaha berbasis biologi dengan motivasi siswa dalam berwirausaha berbasis biologi di SMA N 98 Jakarta. Hal ini menunjukkan bahwa hubungan kedua variabel searah, sehingga apabila self efficacy dalam berwirausaha berbasis biologi siswa SMA semakin tinggi, maka motivasi berwirausaha yang dimiliki semakin tinggi pula. Sejalan dengan pernyataan (Bandura, 1994) bahwa self efficacy dapat membentuk proses motivasi dan selanjutnya akan mempengaruhi tingkah laku seseorang. Berdasarakan teori tersebut, dapat dijelaskan bahwa antara self efficay dengan motivasi memiliki hubungan.

Berdasarkan hasil penelitian ini diperoleh nilai rata-rata self efficacy siswa dalam berwirausaha berbasis biologi di SMA N 98 Jakarta termasuk ke dalam kategori tinggi. Tingginya nilai self efficacy siswa dalam berwirausaha berbasis biologi dikarekanakan keyakinan yang dimiliki oleh siswa untuk mampu dalam berwirausaha.

Hasil menunjukan bahwa dimensi menentukan tujuan inti adalah yang paling dominan pada self efficacy siswa dalam berwirausaha berbasis biologi. Dimensi ini menentukan bagaimana keyakinan seseorang terhadap visi, mempertahankan visi, dan pengelolaan tim. Sebelum berwirausaha berbasis biologi, siswa terlebih dahulu merencanakan usahanya secara mandiri. Siswa menetukan tujuan usaha, produk yang akan dibuat, melihat kebermanfaatan produk bagi masyarakat dan lingkungan, serta analisis keutungan usaha. Hal ini tentu menjadikan pengalaman yang nyata bagi siswa. Sesuai dengan pernyataan (Bandura, 1994) bahwa sumber dari self efficacy dapat diperoleh salah satunya dari penguasaan pengalaman (mastery experience).

Saat berwirausaha berbasis biologi siswa juga bekerja secara berkelompok, dengan setiap kelompok berjumlah empat siswa. Adanya kerja sama dengan teman, dan melihat kelompok lain dapat sukses dalam berwirausaha berbasis biologi (produk laku 
terjual dan mendapatkan keuntungan) dapat meningkatkan self efficacy. Sesuai dengan pernyataan (Bandura, 1994) mengatakan sumber lain dari self efficacy adalah dengan adanya pengalaman orang lain (vicarious experience). Seseorang yang melihat orang lain sukses, akan meningkatkan self efficacy. (Zhao et al, 2005; Radu dan Love, 2008 dalam Melebana dan Swanepoel, 2014) juga mengatakan bahwa self efficacy dalam berwirausaha dapat dibangun melalui pendidikan kewirausahaan. Hal serupa juga dikatakan oleh (Segal, Schoendfeld dan Borgia, 2007 dalam Melebana dan Swanepoel, 2014) mengatakan bahwa pendidikan kewirausahaan memiliki dampak yang positif sebagai sumber self efficacy.

Siswa yang telah merasa yakin untuk berwirausaha berbasis biologi maka semakin termotivasi untuk berwirausaha. Hal ini sesuai dengan pernyataan (Pintrinch dan DeGroot 1990 dalam Lai, 2011) seseorang yang memiliki self efficacy tinggi, akan lebih termotivasi dan sukses dalam menyelesaikan suatu tugas. Sejalan dengan pernyataan (Bandura, 2006 dalam Malebana, 2104) bahwa self efficacy dalam berwirausaha dapat mempengaruhi motivasi dalam berwirausaha yang berdampak pada tujuan, aspirasi individu dan bagaimana mereka melihat peluang serta hambatan. Seeseorang merasa yakin untuk menghadapi suatu tantangan, maka seseorang akan terdorong untuk melakukan kegiatan itu (Uno, 2007).

Hasil penelitian menunjukan dimensi yang paling dominan pada motivasi siswa dalam berwirausaha berbasis biologi adalah kebutuhan yang tersedia. Dimensi ini terdiri atas kebutuhan keuangan, fasilitas dan jaringan sosial. Seseorang yang akan mendirikan sebuah usaha harus didukung dengan ketersediaan kebutuhan. Seorang calon pengusaha akan sulit berwirausaha, jika sumber daya dan sumber pasokan di lingkungan tidak tersedia, seperti bahan baku yang tersedia di alam, peralatan yang memadai, dan modal. Ketersediaan kebutuhan menjadi "kunci" dari motivasi berwirausaha (Laundry et al, 2006 dalam Morales-Gualdron, 2008). Hal ini juga sejalan dengan (Achfusi dan Umeh, 2011) yang mengatakan bahwa untuk berwirausaha berbasis biologi membutuhkan sumber daya manusia dan material pendukung.

Self efficacy siswa dalam berwirausaha berbasis biologi memberikan kontribusi terhadap motivasi siswa dalam berwirausaha berbasis biologi sebesar 52,5\%, sedangkan 47,5\% diduga disebabkan oleh faktor lain yang tidak diteliti dalam penelitian ini. Cukup besarnya kontribusi yang diberikan self effycacy terhadap motivasi dalam berwirausaha berbasis biologi membuat siswa lebih yakin untuk memulai usaha berbasis biologi.

\section{KESIMPULAN}

Berdasarkan hasil penelitian dan pengujian hipotesis yang telah dilakukan, dapat disimpulkan bahwa terdapat hubungan positif antara self efficacy dalam berwirausaha berbasis biologi dengan motivasi siswa dalam berwirausaha berbasis biologi. Hubungan antara kedua variabel tersebut memiliki hubungan yang kuat

\section{UCAPAN TERIMAKASIH}

Dra. Ernawati, M.Si selaku Dosen Pembimbing I dan Erna Heryanti, M.Si selaku Dosen Pembimbing II. Eka Putri Azrai, S.Pd, M.Si. selaku Dosen Penguji I dan Dra. Nurmasari S, M.Biomed selaku Dosen Penguji II. Dr. Diana Vivanti M.Si selaku 
Ketua Program Studi Pendidikan Biologi dan seluruh jajaran dosen Prodi Pendidikan Biologi dan Biologi.

\section{DAFTAR PUSTAKA}

Achfusi, J.L dan Umeh M.O (2011). Entrepreneurial and Functional Biology Education: Veritable Tools for Achieving The national Objectives of Vissions 20:2020. Multidisciplinary Journal of Research Development.

Bandura, A. (1994). Self-efficacy. In V. S. Ramachaudran (Ed.), Encyclopedia of human behavior . New York: Academic Press.

Drnovsek, M et al. (2010). Entrepreneurial self-efficacy and business strat-up: developing a multi-dimensional definition. International Journal of Entrepreneurial Behavior \& Research.

Lai, Emily R. (2011), Motivation : a literature review. Rearch report

Malebana, J.M (2014). Entrepreneurial Intentions and Entrepreneurial Motivation of South African Rural University Students. Tshwane University of Technology, South Africa. Journal of Economics and Behavioral Studies.

Melebana dan Swanepoel (2014). The Relationship between Exposure to Entrepreneurship Education and The Entrepreneurial Self-efficacy. University of South Africa. Southern African Business Review.

Meredith, G. Goffrey. (1996). Kewirausahaan: Teori dan praktik. Jakarta : Pustaka Binaman Pressindo.

Morales-Gualdron, S.T. (2008). The entrepreneurial motivation in academia: a multidimensional construct, INGENIO Working Paper Series.

Uno, Hamzah. B. (2007). Teori Motivasi dan Pengukuranya: Analisis di Bidang Pendidikan. Jakarta: PT.Bumi Aksara.

Wahyudi, Sandy. (2012). Entrepreneuial Branding and Selling Road Map Menjadi Entrepreneur Sejati. Yogyakarta:Graha ilmu Widiasarana Indonesia. 